\title{
Delayed Orgasm
}

National Cancer Institute

\section{Source}

National Cancer Institute. Delayed Orgasm. NCI Thesaurus. Code C78252.

Sexual dysfunction characterized by a delay in climax. 